\title{
DOKTORANDSKÉ PŘíSPĚVKY
}

\section{Ustanovení o použití jiných právních předpisů v dvoustranných dohodách o podpoře a ochranĕ mezinárodních investic}

\section{Provision on Application of other Rules in Bilateral Treaties on Promotion and Protection of Investments}

\author{
Ivan Cisár ${ }^{*}$
}

\begin{abstract}
Abstrakt
Ustanoveni o pouð̌ití jiných právních predpisù je pravidelně soućástí dvoustranných smluv o podpoře a ochraně mezinárodních investic. I kedyžj jde o ustanovení, keterébo se investori dovolávaji jenom zrúdka, jejich snahou je tímto ustanovením odvrátit negativni roz̧hodnuti týkajíci sa typičtéjšich ustanoveni dvoustranných investičnich smluv. Investori se pokoušeji takováto ustanoveni vykládat jako variace na zastrésujici klauzuli nebo doložku nejvyššcich výhod. Tento clánek analyzuje interpretaci zvolenou investori v jednotlivých prípadech a roz̧odnuti tribunálu. Cílem je poskytnout vlastni interpretaci účlu a obsahu takovýchto ustanovení.
\end{abstract}

Klíčová slova

dvoustranné smlouvy o podpoř a ochranè investic; pouřití jiných prèdpisui; zacházeneni.

\begin{abstract}
Provision on application of other rules is one of the common provisions included regularly into the bilateral investment treaties. Although, the provision itself is raised by investors or host states in investment arbitration sparsely, it has been raised by the investors to overcome negative decisions on more standard provisions under the bilateral investment treaties. Investors have attempted to interpret this provision either as variation of umbrella clause or most-favoured nation clause. This article is analysing interpretations provided by the investors and the determinations of the arbitral tribunals. The aim is to provide own interpretation of purpose and content of these provisions.
\end{abstract}

Keywords

Bilateral Investment Treaties; Application of Other Rules; Treatment.

\footnotetext{
* Mgr. Ivan Cisár, doktorand, Katedra mezinárodního a evropského práva, Právnická fakulta Masarykovy univerzity, Brno / Ph.D. student, Department of International and European Law, Masaryk University, Brno, Czech Republic / E-mail: cisar.ivan@gmail.com
} 
V současnosti je mezi jednotlivými státy světa uzavřeno přibližně 3000 dvoustranných dohod o vzájemné podpoře a ochraně investic. ${ }^{1}$ I navzdory této bohaté dvoustranné mezinárodně právní regulaci je možné vysledovat, že se jisté prvky v těchto smlouvách pravidelně opakují. Z oblasti hmotně právní úpravy jde zejména o garance nebo standardy spravedlivého a rovného zacházení (,fair and equitable treatment'), plné ochrany a bezpečnosti (,full protection and security ${ }^{\circ}$ ) a realizace vyvlastnění nebo jiného obdobného zásahu do investice jenom na základě zákona na nediskriminačním základě a proti okamžité, odpovídající a efektivní náhradě (tzv. Hullova formule) ${ }^{2}$ investorům druhé smluvní strany. Pravidelnou součástí dvoustranných dohod o ochraně investic bývají ještě tzv. doložky národního zacházení (garance poskytnutí zacházení investorům ne méně příznivého než jaké je poskytované vlastním investorům a investicím - ,national treatment') a nejvyšších výhod (garance poskytnutí zacházení ne méně prríznivého než jaké je poskytováno investorům z třetích států, myšleno států, které nejsou smluvními stranami předmětné dvoustranné dohody - „most favoured nation clause“), jejichž účelem je srovnání podmínek mezi investory z třetích států a domácími investory v oblasti investic na území daného státu.

Pravidelnou součástí dvoustranných dohod o vzájemné podpoře a ochraně investic je i procesně právní problematika, která umožňuje investorům z druhého smluvního státu přesunout právní řešení případného sporu z národních soudů hostitelského státu investice na mezinárodní rozhodčí tribunál. ${ }^{3}$ Toto ustanovení bývá považováno za jednu

1 Konference Organizace spojených národů o obchodu a rozvoji (United Nations Conference on Trade and Development (UNCTAD)) eviduje v současnosti 2932 uzavřených dvoustranných dohod o podpoře a ochraně investic, z kterých je 2286 účinných. Viz http://investmentpolicyhub.unctad.org/IIA [cit 11. 10. 2015].

2 „, $[\mathrm{U}]$ nder every rule of law and equity, no government is entitled to expropriate private property, for whatever purpose, without provision for prompt, adequate and effective payment thereof." Citováno z SORNARAJAH, M. The international law on foreign investment. 3rd ed. New York: Cambridge University Press, 2010, xxx, 524 p. ISBN 9780521747653, s. 36. Viz i např. DOLZER, Rudolf a Christoph SCHREUER. Principles of international investment law. 2nd ed. Oxford: Oxford University Press, 2012, xxxvi, 417 s. ISBN 978-0-19-965180-1, s. $2-4$.

3 V současnosti jde o zásadně standardní součást těchto dohod. V československé, potažmo české praxi sjednávání těchto dohod můžeme nalézt minimálně počáteční odpor k takovémuto řešení, který se opíral o soudobou teorii mezinárodního práva a zejména suverenitu státu, na kterou odkazovali zejména socialistické státy. Překonání tohoto odporu způsobila skutečnost, že další státy (zejména jak bylo uváděno v soudobých dokumentech - vyspělé kapitalistické) nebyly ochotny sjednávat takovéto smlouvy bez tohoto řešení, což po vzoru Sovětského svazu uznalo i Československo. Viz např. Dokument Federálního ministerstva financí, č. j. III/1-16.034/88, Př́loha II, Zpráva pro vládu Československé socialistické republiky o návrhu na sjednání Dohody mezi Československou socialistickou republikou a Hospodářskou unií belgicko-lucemburskou o vzájemné podpoře a ochraně investic, s. 4-5: „Ve všech dohodách o vzájemné podpore a ochrané investic, které dosud uzavrély europské socialistické státy, je zakeotven článeke, ketery upravuje rèsené tzv. diagonálních sporu se stejním nebo obdobným obsahem jako zni nedobodnuty článek 8 predkládanébo návrbu dohody. [...] Sovétská strana dospèla k závèru, že dohody o vájemné ocbrané investic se nepodař s kapitalistickými státy uzavrít, aniž by se prìstoupilo na zapracováni článku upravijicíbo roz̧hodováni diagonálnich spori. Př̈ projednávani tèchto dohod však, prosazuje, aby v nich byl vymezen okrubu spori, které mezi investorem z jednoho státu a státem (tj. státním orgánem) mohou být vedeny. Pod zminènými komerčnimi spory rozumi sovètská strana zejména poskytnutou vy̌ši nábrady prì likvidaci resp. vyvlastnèní podniku." 
z nejvýznamnějších inovací, které dvoustranné dohody o ochraně investic přinesly. ${ }^{4}$

Další pravidelně se opakující součástí dvoustranných dohod o podpoře a ochraně investic je ustanovení, které bývá často označováno rubrikou „použití jiných předpisů a další závazky“. V současnosti platné dvoustranné dohody o podpoře a ochraně investic, kterými je Česká republika vázána (dohromady cca 80$)^{5}$ takovéto ustanovení vesměs obsahuji. ${ }^{6}$ I když jde o pravidelnou součást dvoustranných dohod, jde o ustanovení, kterému teorie obvykle nevěnuje zvláštní pozornost a ani není v praxi aplikováno tak často, jako jiná ustanovení.

Předmětem tohoto př́spěvku je analýza ustanovení o použití jiných předpisů na základě př́kladů z praxe, kdy bylo součástí argumentace jedné ze stran sporu (nejčastěji investora) a podrobeno případné reakci rozhodčího tribunálu. Cílem je zodpovězení otázky, jaký je účel předmětného ustanovení, a př́padně, zda jde o ustanovení, které poskytuje investorům další možnosti domoci se mezinárodní ochrany svých investic na jedné straně a ukládá hostitelským státům takovýchto investic další povinnosti nad rámec výše uvedených standardů, nebo překoná alespoň jejich omezený rozsah daný formulací v jednotlivých dvoustranných dohodách.

V současnosti je problematika řešení investičních sporů mezinárodními rozhodčími tribunály opětovně široce diskutována. Podklad pro probíhající diskusi tvoří zejména zkušenosti s případnými individuálními př́pady, které byly, případě by mohly být vůči některým státům předloženy rozhodčím tribunálům. Viz např. změnu př́istupu Austrálie k sjednávaní dohod bez úpravy řešení sporů mezi investorem a hostitelským státem prostřednictvím arbitráže - PETERSON, Luke. In policy switch, Australia disavows need for investor-state arbitration provisions in trade and investment agreements, IAReporter, 14. duben 2011, dostupné na http://www.iareporter.com/articles/in-policy-switch-australia-disavows-need-for-investor-state-arbitration-provisions-in-trade-and-investment-agreements/ [cit. 26. 10. 2015]; nebo diskusi vyvolanou procesem sjednávaní dohod o volném obchodu mezi Evropskou unií a Kanadou, Singapurem a zejména Spojenými státy americkými, viz např. PETERSON, Luke. European Commission favours more judicialization of ISDS in near term - a multilateral court in the longer term, LAReporter, 5. březen 2015, dostupné na http://www.iareporter.com/articles/european-commission-favors-more-judicialization-of-isds-in-near-term-a-multilateral-court-in-the-longer-term/ [cit. 26. 10. 2015]; výsledky konzultace zahájené Evropskou komisí k použití rozhodčího říení na řešení sporů mezi investorem a hostitelským státem ukončena 13. července 2014, dostupné na http://trade.ec.europa.eu/consultations/index.cfm?consul_id=179 [cit. 26. 10. 2015].

4 Viz např. rozhodnutí ve věci European American Investment Bank AG (EURAM) v. Slovak Republic, UNCITRAL, Award on Jurisdiction, 22 October 2012, p. 443; nebo odlišné stanovisko Antonia Crivellara v prrípadě SGS Société Générale de Surveillance S.A. v. Republic of the Philippines, ICSID Case No. ARB/02/6, Declaration (Dissenting Opinion of Antonio Crivellaro), 29 January 2004, p. 6.

5 Přehled těchto dohod zveřejňuje na svých webových stránkách Ministerstvo financí. Přehled s odkazy na oficiální texty je dostupný na http://www.mfcr.cz/cs/legislativa/dohody-o-podpore-a-ochrane-investic/ prehled-platnych-dohod-o-podpore-a-ochra\#word_v

6 Viz přehled uzavřených dohod o ochraně investic uvedený níže v kapitole 3. 


\section{Použití ustanovení ,jiné předpisy a další ustanoveni““ $\mathrm{v}$ rozhodovací praxi rozhodčích tribunálů}

\subsection{Použití ustanovení o jiných předpisech v případech souvisejících s dvoustrannými dohodami uzavíranými Českou republikou}

Jediným zaznamenaným případem, kdy investor argumentoval použitím článku o jiných předpisů, proti České republice, je př́pad William Nagel v. Ceská republika rozhodovaný na základě dohody uzavřené se Spojeným královstvím.

Česká republika v tomto případě tvrdila, že aby bylo možné posoudit existenci investice W. Nagela, není možné ignorovat národní právo, ${ }^{7}$ dle kterého soukromoprávní smlouva, na kterou se odvolával W. Nagel jako na svou investici, nebyla platně uzavřena, a tak není ani dána investice W. Nagela. ${ }^{8}$ Argumentace ustanovením o jiných předpisech ${ }^{9}$ byla vznesena žalobcem W. Nagelem jako součást obrany proti této argumentaci státu. Naopak, W. Nagel se snažil vyloučit aplikaci národní práva, když tvrdil, že otázky, které nejsou výslovně řešeny dohodou, mají byt řešeny dle mezinárodního práva a ne práva národního. $\mathrm{V}$ tomto kontextu poukázal i na ustanovení o jiných předpisech, které zjevně považoval za jedinou možnost, jak by mohlo být národní právo aplikovatelné. Dle W. Nagela je v jeho věci použití národního práva (na základě ustanovení o jiných předpisech) vyloučeno, protože pro něj neobsahuje úpravu výhodnějšího zacházení. ${ }^{10}$

Taktéž se W. Nagel snažil využít ustanovení o jiných předpisech jako obranu proti argumentaci státu, že jeho př́padné nároky jsou již promlčeny dle českého práva, které má tribunál použít, jelikož jde o nejvhodnější (ve smyslu mezinárodní práva soukromého) právní řád s nejužším vztahem $\mathrm{k}$ dané problematice. ${ }^{11} \mathrm{I} \mathrm{v}$ tomto kontextu použil obdobné důvody odkazující na nepríípustnost aplikace národního práva. ${ }^{12}$

Rozhodčí tribunál se, bez odkazu a analýzy ustanovení o jiných předpisech, vyjádřil jenom k prvnímu argumentu. Ohledně existence investice uznal její navázaní na národní

7 Dohoda mezi vládou České a Slovenské Federativní Republiky a vládou Spojeného království Velké Británie a Severního Irska o podpoře a ochraně investic ze dne 10. července 1990, čl. 1 písm. a): „pojem „investice" označuje všechna aktiva náležejicí investorovi jedné smluvni strany na územi drubé smluvni strany v souladu s právním rádem této drubé smluvni strany v jakémkoli oboru hospodár ŕtví..."

8 William Nagel v. The Czech Republic, SCC Case No. 049/2002, Final Award, 9 September 2003, pp. 182-185.

9 Dohoda mezi vládou České a Slovenské Federativní Republiky a vládou Spojeného království Velké Británie a Severního Irska o podpoře a ochraně investic ze dne 10. července 1990, čl. 11 - Použití jiných předpisů: „Jestliže právni predpis některé ze smluvnich stran nebo závazek existujicí v současnosti nebo v budoucnu podle mezinárodního práva mezi smluvnimi stranami vedle této Dohody obsahuje pravidla, at' už obecná nebo zulástní, opravnúuici investice investoru drubé smluvni strany k zacházení výhodnèjsímu než jaké je dáno touto Dobodou, budou tato pravidla v rozsahu, ve keterém jsou výhodnèjš́, mit prednost prè touto Dohodou."

10 Ibid, p. 77.

11 Ibid, pp. 250-256.

12 Ibid, p. 127. 
právo, které svou působností vytváří hodnotu investice. ${ }^{13}$ Jelikož následně tribunál dospěl k závěru, že žádnou investici W. Nagel na území České republiky neměl, ${ }^{14}$ zdá se pravděpodobné, že tribunál již považoval další argumentaci ohledně použití ustanovení o jiných předpisech za nadbytečnou. Proto $v$ tomto př́padě vlastně nenalezneme interpretaci ustanovení o jiných předpisech ze strany tribunálu, ale jenom z pohledu jedné ze stran.

Další př́ipad, který byl rozhodovány na základě dvoustranné dohody obsahující ustanovení obdobně českým dohodám o ochraně investic, je př́pad Accession Mezzanine rozhodovaný na základě mad'arsko-britské smlouvy o ochraně investic. ${ }^{15} \mathrm{~V}$ tomto př́padě se žalobci snažili využít ustanovení o jiných předpisech ${ }^{16}$ za účelem rozšíření pravomoci rozhodčího tribunálu, jelikož dle předmětné dohody je rozsah sporů, které mohou být předloženy rozhodčímu tribunálu, omezen. ${ }^{17}$

Žalobci se snažili rozšsiríit pravomoc tribunálu tak, aby mohl posoudit otázku vyvlastnění ne jen na základě úpravy v dvoustranné dohodě, ale taktéž na základě obyčejového mezinárodního práva. Obyčejové mezinárodní právo mělo být použito právě na základě ustanovení o jiných předpisech. ${ }^{18}$

Mad'arsko oponovalo, jelikož dle jeho názoru ustanovení o jiných předpisech nerozšiřuje rozsah rozhodčí doložky na spory ohledně obyčejového mezinárodního práva stejně, jako nerozšiřuje rozsah doložky na spory ohledně národního práva. ${ }^{19}$

13 Ibid, p. 300.

14 Ibid, p. 335.

15 Tato dohoda spolu s mnohými dalšími dohodami sjednávanými někdy ještě socialistickými státu od r. 1985 do přibližně r. 1993, sdílí mnohé společné prvky dané obdobím a prostředím, kde vznikala. V tomto období ještě dobíhal proces sjednávání, podpisu a ratifikace dvoustranných dohod, který byl zahájen ještě před změnou ekonomického systému v státech střední a východní Evropy a postupným prechodem na kapitalistický ekonomický systém, a s tím spojeným vývojem právního nazírání (doktríny mezinárodního práva) na ochranu investic a investorů z třetích států,

16 Agreement between the Government of the United Kingdom of Great Britain and Northern Ireland and the Government of the Hungarian People's Republic for the Promotion and Reciprocal Protection of Investments, čl. 11 - Application of other Rules: „If the provisions of law of either Contracting Party or obligations under international law existing at present or established hereafter between the Contracting Parties in addition to the present Agreement contain rules, whether general or specific, entitling investments by investors of the other Contracting Party to a treatment more favourable than is provided for by the present Agreement, such rules shall to the extent that they are more favourable prevail over the present Agreement."

17 Agreement between the Government of the United Kingdom of Great Britain and Northern Ireland and the Government of the Hungarian People's Republic for the Promotion and Reciprocal Protection of Investments, čl. 8 odst. 1: „Each Contracting Party hereby consents to submit to [ICSID]... any legal dispute arising under Article 6 of the Agreement [Expropriation] between that Contracting Party and an investor of the other Contracting Party concerning an investment of the latter in the territory of the former."

18 Accession Merzanine Capital L.P. and Danubius Kereskedöbáz. Vagyonkezelö Zrt. v. Hungary, ICSID Case No. ARB/12/3, Decision on Respondent's Objection under Arbitration Rule 41(5), 16 January 2013, p. 56.

19 Ibid, p. 51. 
Tribunál analyzoval účinky ustanovení o jiných předpisech společně s čl. 3 předmětné dohody, který obsahuje doložku nejvyšších výhod. Samotný tribunál obě ustanovení označoval společně jako doložky nejvyšších výhod. Dle názoru tribunálu žádná z těchto doložek, a v kontextu předmětu tohoto článku pak zejména ustanovení o použití jiných předpisů, nemůže být vykládána tak, že by umožnila vznik nového základu pro nárok nad rámec těch, které již jsou výslovně uvedeny v dané dohodě. ${ }^{20} \mathrm{~V}$ tomto případě to znamená, že žalobci se nemohli dovolávat tvrzeného nároku z údajně porušené záruky ohledně vyvlastnění, jak by byla stanovena v obyčejovém mezinárodním právu. Žalobci se tak mohli dovolávat jenom tvrzeného nároku z údajného porušení garancí ohledně vyvlastnění, jak jsou stanoveny v předmětné dohodě. ${ }^{21}$

\subsection{Použití ustanovení o jiných předpisech v př́ípadech rozhodovaných na základě dalších dvoustranných dohod}

Úplně prvním případem, ve kterém byla řešena otázka účinků ustanovení o použití jiných ustanovení, byl případ Yang Chi Oo Trading, který byl rozhodován na základě Rámcové dohody ASEAN o investiční zóně ASEAN. Tato dohoda obsahuje i ustanovení, které vymezuje použitelnost starších úmluv př̌ijatých na půdě ASEAN. ${ }^{22}$

Investor se $\mathrm{v}$ tomto př́padě dovolával úmluvy ASEAN o podpoře a ochraně investic z r. 1987,,$^{23}$ která nebyla přímo aplikovatelná na předmětný spor. Investor chtěl využít právě ustanovení o jiných předpisech na to, aby se dovolal ustanovení, která byla podle jeho názoru pro něj lepší a výhodnější (šlo zejména o procesní ustanovení). ${ }^{24}$

Tribunál však s argumentací žalobce nesouhlasil. Dle názoru tribunálu nic ve znění předmětného článku nenaznačuje, že by chtěly strany sjednávající Rámcovou dohodu z r. 1998 rozšíríit původní úmluvu z r. 1987 i na předměty dle Rámcové dohody. ${ }^{25}$ Tribunál proto došel k závěru, že prostřednictvím tohoto článku není možné vytvořit nové právo (nový nárok), kterého by se mohl dovolávat žalobce. ${ }^{26}$

\footnotetext{
20 Ibid, p. 73.

21 Ibid, p. 74.

22 Framework Agreement on the ASEAN Investment Area ze dne 7. řijna 1998, čl. 12: „Other Agreements 1. Member States affirm their existing rights and obligations under the 1987 ASEAN Agreement for the Promotion and Protection of Investments and its 1996 Protocol. In the event that this Agreement provides for better or enhanced provisions over the said Agreement and its Protocol, then such provisions of this Agreement shall prevail. 2. This Agreement or any action taken under it shall not affect the rights and obligations of the Member States under existing agreements to which they are parties. 3. Nothing in this Agreement shall affect the rights of the Member States to enter into other agreements not contrary to the principles, objections and terms of this Agreement."

23 ASEAN Agreement for the Promotion and Protection of Investments ze dne 15. prosince 1987.

24 Yaung Chi Oo Trading Pte. Ltd. v. Government of the Union of Myanmar, ASEAN I.D. Case No. ARB/01/1, Award, 31 March 2003, p. 79.

25 Ibid, p. 80.

26 Ibid, p. 82.
} 
$\mathrm{Na}$ tento prípad bylo odkázáno i následně ve věci $S G S v$. Filipiny. ${ }^{27} \mathrm{~V}$ této věci nešlo ani tak o aplikaci a interpretaci ustanovení ohledně použitelnosti dalších předpisů. ${ }^{28} \mathrm{~V}$ případě švýcarsko-filipínské dvoustranné dohody je totiž ustanovení ohledně použitelnosti dalších předpisů, které je jindy uváděno v samostatném článku, součástí článku, který v dalším odstavci obsahuje proslulou tzv. zastřešující klauzuli, která byla hlavním předmětem zájmu tribunálu. ${ }^{29}$

Tribunál konstatoval, že ustanovení o použití dalších předpisů (v čl. X odst. 1) řeší jen vztahy mezi závazky státu ujednanými v dvoustranné dohodě o ochraně investic a závazky/povinnostmi z národního práva a ostatních aplikovatelných pramenů mezinárodního práva. Dle tribunálu, nic v tomto článku neukládá státu žádné další povinnosti v rámci kontextu úpravy ochrany investic $\mathrm{v}$ dvoustranné právní úpravě. ${ }^{30}$

Dalším prrípadem, je případ Salini v Jordánsko rozhodovaný na základě dvoustranné dohody mezi Itálií a Jordánskem. ${ }^{31} \mathrm{~V}$ tomto př́ípadě se žalobce dovolával ustanovení o použití jiných ustanovení ${ }^{32}$ pod společnou hlavičkou tzv. zastřešující klauzule spolu s dal-

27 Znalost tohoto rozhodnutí mohl pro práci tribunálu v SGS zprostředkovat soudce Crawford, který působil u obou pŕṕpadů.

28 Agreement between the Republic of the Philippines and the Swiss Confederation on the promotion and reciprocal protection of investments ze dne 31. března 1997, čl. X odst. 1: „If the provisions in the legislation of either Contracting Party or rules of international law entitled investments by investors of the other Contracting Party to treatment more favourable than is provided for by this Agreement, such provisions shall to the extent that they are more favourable prevail over this Agreement."

29 Agreement between the Republic of the Philippines and the Swiss Confederation on the promotion and reciprocal protection of investments ze dne 31. března 1997, čl. X odst. 2: „Each Contracting Party shall observe any obligation it has assumed with regard to specific investments in its territory by investors of the other Contracting Party."

30 SGS Société Générale de Surveillance S.A. v. Republic of the Philippines, ICSID Case No. ARB/02/6, Decision of the Tribunal on Objection to Jurisdiction, 29 January 2004, p. 114.

31 Agreement between the Government of the Hashemite Kingdom of Jordan and the Government of the Italian Republic on the Promotion and Protection of Investments ze dne 21. července 1996.

32 Agreement between the Government of the Hashemite Kingdom of Jordan and the Government of the Italian Republic on the Promotion and Protection of Investments ze dne 21. července 1996, čl. 11: "Application of other Provisions 1. If a matter is governed both by this Agreement and another International Agreement to which both Contracting Parties are signatories, or by general international law provisions, the most favourable provisions shall be applied to the Contracting Parties and to their investors. 2. Whenever the treatment accorded by one Contracting Party to the investors of the other Contracting Party according to its laws and regulations or other provisions or specific contract or investment authorizations or agreements, is more favourable than that provided under this Agreement, the most favourable treatment shall apply. In case the host Contracting Party has not applied such treatment, in conformity with the above, and the investor suffers a damage as a consequence thereof, the investors shall be entitled to a compensation of such damages in conformity with Article 4. 3. Whenever, after the date when the investment has been made, a modification should take place in laws, regulations, acts or measures of economic policies governing directly or indirectly the investment, the same treatment will apply upon request of the investor that was applicable to it at the moment when the investment had been carried out." 
ším ustanovením dohody. ${ }^{33}$ Svou argumentaci žalobce směřoval k tomu, aby tribunál akceptoval svou pravomoc ohledně nároků vyplývajících ze smlouvy mezi investorem a Jordánskem ohledně výstavby projektu vodní nádrže Karameh. ${ }^{34}$

Tribunál se vyjádřil jenom stručně k obsahu ustanovení o jiných předpisech. I když to výslovně neuvedl, z argumentace je zjevné, že odmítl akceptovat interpretaci předmětného ustanovení o jiných předpisech jako zastřešující klauzule. Dle názoru tribunálu obecně oba odstavce předmětného článku odkazují na nejvýhodnější zacházení s investorem. ${ }^{35}$ Zvláštností v tomto př́ipadě aplikovatelné doložky (čl. 11 odst. 2) od ostatních př́ípadů klauzule o použití jiných předpisů je výslovná úprava možnosti domáhat se odškodnění, když takovéto nejvýhodnější zacházení není investorovi poskytnuto. Avšak ani tato skutečnost, na kterou tribunál odkázal jen prostou citací této části ustanovení o jiných předpisech, ${ }^{36}$ nebránila tribunálu dojít s poukazem na předchozí rozhodnutí ve věcech SGS v. Filipiny a Yang Chi Oo Trading k závěru, že jde o př́pad „without prejudice clause“, který nemůže zpo̊sobit zahrnutí závazků ze smlouvy mezi investorem a státem, které obsahuje, do dvoustranné dohody o ochraně investic. ${ }^{37}$

Další případ, kdy byla tvrzena použitelnost ustanovení o dalších závazcích, byl případ M.C.I. Power v. Ekvádor rozhodovaný na základě dvoustranné dohody mezi Spojenými státy americkými a Ekvádorem. ${ }^{38}$ Tento případ je zajímavý tím, že nešlo o uplatnění ustanovení o použití jiných předpisů ze smlouvy, na základě které byl rozhodován daný spor, ale o inkorporaci tohoto ustanovení z jiné smlouvy, konkrétně smlouvy uzavřené mezi Argentinou a Ekvádorem, na základě aplikace doložky nejvyšších výhod. ${ }^{39}$ Důvodem takovéto konstrukce žalobcovy argumentace byla snaha dosáhnout rozšírení aplikovatelnosti dohody mezi USA a Ekvádorem i na př́ípady, kdy investice zanikla ještě před vstupem této dohody v účinnost, jelikož většina kroků Ekvádoru, proti kterým brojil

33 Agreement between the Government of the Hashemite Kingdom of Jordan and the Government of the Italian Republic on the Promotion and Protection of Investments ze dne 21. července 1996, čl. 2 odst. 4) a 5): „4. Each Contracting Party shall create and maintain in its territory a legal framework apt to guarantee to investors the continuity of legal treatment, including the compliance, in good faith, of all undertakings assumed with regard to each specific investor. 5. Each Contracting Party or its designated Agency may stipulate with an investor of the other contracting Party an investment agreement which will govern the specific legal relationship related to the investment of the investor concerned."

34 Salini Costruttori S.p.A. and Italstrade S.p.A.v. The Hashemite Kingdom of Jordan, ICSID Case No. ARB/02/13, Decision on Jurisdiction, 9 November 2004, p. 120.

35 Ibid, p. 129.

36 Ibid, p. 129.

37 Ibid, p. 130.

38 Treaty between the United States of America and the Republic of Ecuador concerning the Encouragement and Reciprocal Protection of Investment, ze dne 27. srpna 1993.

39 M.C.I. Power Group LC and New Turbine Incorporated v Ecuador, ICSID Case No ARB/03/6, 26th July 2007, Award, p. 56. 
investor, se stala, a vưči jeho investici měla zničující efekt, ještě před vstupem smlouvy v účinnost. ${ }^{40}$

Dle názoru žalobce, ustanovení čl. VII dohody mezi Argentinou a Ekvádorem obsahuje tezi času, že prostřednictvím odkazu na dohody uzavřené mezi smluvními stranami (za účelem ochrany investic) odkazuje i na ještě neuzavřené úmluvy. Klíčovým mělo být časové hledisko aplikovatelných norem na namítané zacházení, které chtěl investor aplikovat i na sebe, a ne o specifikaci, zda daná jiná pravidla musejí být ujednána (a tedy jsou závazná) mezi těmito konkrétními smluvními stranami. ${ }^{41}$

Tribunál odmítl takovouto konstrukci. Ustanovení vyložil tak, že odkaz na smluvní strany explicitně referuje na smluvní strany smlouvy, tj. Argentinu a Ekvádor. ${ }^{42}$ Po tomto shrnutí již jenom kategoricky prohlásil, že toto ustanovení není možné vykládat tak, jak to činí žalobce. ${ }^{43}$ Není tedy možné odkazem na ustanovení, které hovoří o př́padných budoucích vzájemných závazcích, které mohou být příznivější pro investora, posouvat účinnost smlouvy na dobu před tím, než sama stanoví.

V prípadě Nordzucker v. Polsko, který byl rozhodovaný na základě dvoustranné dohody mezi Německem a Polskem, se na ustanovení o použití jiných ustanovení ${ }^{44}$ dovolával žalobce jako na jeden z důvodů, kterým se snažil dosáhnout aplikace dodatkového protokolu $\mathrm{k}$ předmětné dohodě upravujícího rozsah doložky o řešení sporů v předmětné dohodě. Tento protokol limitovanou doložku o řešení sporů rozšiřoval na jakékoliv porušení dvoustranné dohody. Žalobce považoval protokol měnící původní text dohody za takovou mezinárodní smlouvu, která poskytuje výhodnější zacházení. Tribunál

40 Tato smlouva nerozšiřovala svou působnost na investice, které byly uskutečněny ještě před její účinností, tak činí některé jiné úmluvy. Z těch, které jsou aplikovatelné na investory z nebo v České republice, je to např. Dohoda mezi Českou a Slovenskou Federativní Republikou a Nizozemským královstvím o podpoře a vzájemné ochraně investic ze dne 24. dubna 1991, publikována 569/1992 Sb., čl. 12: „Ustanoveni této Dohody se budou ode dne jejího vstupu v platnost vatahovat rovněž na investice, založené po 1. lednu 1950.“.

41 M.C.I. Power Group, cit. supra no. 39, p. 123. Je vhodné dodat, že smlouva mezi USA a Ekvádorem obsahuje taktéž ustanovení o použití jiných předpisů, avšak s jinými formulacemi, které neodkazují na časový aspekt př́ijetí takovýchto pravidel, proto ji nejspíš investor nezahrnul do své argumentace. Viz Treaty between the United States of America and the Republic of Ecuador concerning the Encouragement and Reciprocal Protection of Investment, ze dne 27. srpna 1993, čl. VIII: „This Treaty shall not derogate form: (a) laws and regulations, administrative practices or procedures, or administrative or adjudicatory decisions of either Party; (b) international legal obligations; or (c) obligations assumed by either Party, including those contained in an investment agreement or an investment authorization, that entitle investments or associated activities to treatment more favorable than that accorded by this Treaty in like situations."

42 M.C.I. Power Group, cit. supra n. 39, p. 127.

43 Ibid, p. 128.

44 Treaty between the Federal Republic of Germany and the People's Republic of Poland concerning the encouragement and reciprocal protection of investmetns, čl. 8 odst. 1: "If the legislation of either Contracting Party or obligations under international law existing at present or established hereafter between the Contracting Parties in addition to this Treaty contain a regulation, whether general or specific, entitling investments by investors of the other Contracting Party to a treatment more favourable than is provided for by this Treaty, such regulation shall to the extent that it is more favourable prevail over this Treaty. " 
ve svém hodnocení uvedl, že toto ustanovení není možné vykládat tak, že by strany dvoustranné dohody chtěly dosáhnout retroaktivních účinků jakýchkoliv změn dvoustranné dohody o ochraně investic i pro prrípady vzniklé ještě před účinností dodatku $\mathrm{k}$ této dohodě. ${ }^{45}$

Ujednání o aplikovatelnosti ustanovení o jiných závazcích, ${ }^{46}$ bylo vzneseno i př́padě TS A Spectrum v. Argentina, který byl rozhodován na základě dohody mezi Holandskem a Argentinou. Na tento článek odkázal a ve své argumentaci ji použil nikoli investor, ale žalovaný stát.

Argentina vznesla několik jurisdikčních námitek. Jedna z nich se týkala uplynutí doby pro smírné řešení sporu, až po uplynutí které je možné zahájit spor před rozhodci (tzv. cooling-off period). Na článek o jiných použitelných předpisech výslovně upozornila Argentina s argumentem, že je nepoužitelný pro případné nahrazení ustanovení o čekací lhůtě jinou z jiné úmluvy. ${ }^{47}$ Za tímto účelem není toto ustanovení možné použít, jelikož odkazuje výslovně na ustanovení jak národního právního řádu aplikovatelného na investici, tak na mezinárodní právo aplikovatelné mezi smluvními stranami, a tedy nevztahující se na mezinárodní úmluvy s třetími státy. ${ }^{48}$

Tribunál shledal, že nesplnění této podmínky není důvodem pro odmítnutí jeho pravomoci, jelikož by šlo o formalistický výklad, který by nezabránil tomu, aby žalobce znovu nezahájil řízení (po skutečném uplynutí předmětné lhůty). ${ }^{49} \mathrm{Z}$ tohoto důvodu se tribunál dále nezabýval př́padným použitím ustanovení o jiných předpisech (stejně jako doložky nejvyšších výhod) na inkorporaci výhodnějšího ustanovení o čekací lhưtě z jiné dvoustranné úmluvy o podpoře a ochraně investic. ${ }^{50}$

45 Nordzucker v. Poland, UNCITRAL, Partial Award (Jurisdiction), 10 December 2008, p. 113(iii). Obdobným prípadem, kdy se investor dovolával retroaktivního zacházení dle jiné dvoustranné dohody na základe doložky nejvyšších výhod byl prrípad Tecmed. Třibunál takýto př́stup taktéž odmítl. Viz Técnicas Medioambientales Tecmed, S.A. v. The United Mexican States, ICSID Case No. ARB (AF)/00/2, Award, 29 May 2003, p. 69.

46 Agreement on encouragement and reciprocal protection of investments between the Kingdom of the Netherlands and the Argentine Republic, čl. 3 odst. 4: „If the provisions of law of either Contracting Party or obligations under international law existing at present or established bereafter between the Contracting Party in addition to the present Agreement contain a regulation, whether general or specific, entitling investments by investors of the other Contracting Party to a treatment more favourable than is provided for by the present Agreement, such regulation shall to the extent that is more favourable prevail over the present Agreement."

$47 \mathrm{~V}$ textu nálezu není indikace, že by se tohoto článku dovolával i žalobce. Je tedy možné, že šlo ze strany Argentiny o preventivní obranu, jelikož se investor dovolával jenom použití doložky nejvyšších výhod v čl. 3 odst. 2. Viz TSA Spectrum de Argentina S.A. v Argentine Republic, ICSID Case No. ARB/05/5, 19 December 2008, Award, pp. 93-94.

48 Ibid, p. 72.

49 Ibid, Award, p. 112.

50 Ibid, p. 114. 
Dalším v řade případů, kdy byla vznesena otázka aplikace ustanovení o použitelnosti jiných předpisů, byl př́pad Spyridon Rousalis v. Rumunsko, který byl rozhodovaný na základě dvoustranné dohody uzavřené mezi Řeckem a Rumunskem. ${ }^{51}$

Žalobce se domáhal přiznání svého domnělého nároku za vyvlastnění. V tomto kontextu se domáhal ochrany nejen na základě ustanovení o vyvlastnění z uplatněné dvoustranné dohody o ochraně investic, ale taktéž se dovolával prvního dodatkového protokolu k Evropské úmluvě o ochraně základních lidských práv, konkrétně čl. 1 věnujícího se ochraně vlastnictví. Žalobce považoval tuto úpravu za pro něho příznivější, než je obsaženo v ustanovení o vyvlastnění v dvoustranné dohodě. ${ }^{52}$ Aby mohlo dojít k uplatnění tohoto ustanovení, žalobce se dovolával ustanovení o jiných předpisech předmětné dohody. ${ }^{53}$

$\mathrm{V}$ tomto př́padě tribunál obecně nevyloučil, že dle ustanovení o jiných předpisech by výhodnější úprava mohla obsahovat i závazky obsažené v mnohostranných úmluvách (včetně Evropské úmluvy). Bez nějaké další analýzy však dospěl k závěru, že v tomto př́ípadě není nutné se touto otázkou zabývat, jelikož úprava $\mathrm{v}$ dvoustranné dohodě o podpoře a ochraně investic je specifičtější a poskytuje vyšší ochranu investorům než obecná úprava mezinárodní ochrany lidských práv. ${ }^{54}$

Ojedinělým případem odkazu na ustanovení o použití jiných předpisů je případ Arif v. Moldávie, kdy se žalobce dovolával ustanovení, které odkazovalo výlučně na specifické závazky převzaté hostitelským státem vůči investorovi. Investor se tohoto ustanovení dovolával s tím, že jde o variaci na tzv. zastřešující klauzuli. Avšak tribunál tuto interpretaci odmítl. Dle tribunálu investor mưže profitovat z výhodnějšího zacházení, ale žádné takové zacházení nemůže přiznat investorovi další nový specifický smluvní nárok. ${ }^{55}$

Zatím posledním případem, kdy tribunál rozhodoval o použití takovéhoto ustanovení je prípad Íckale Inşaat v. Turkmenistán. Investor se ustanovení po použití jiných předpi-

51 Agreement between the government of Romania and the government of the Hellenic republic on the promotion and reciprocal protection of investments, ze dne 16. záŕí 1993.

52 Spyridon Roussalis v. Romania, ICSID Case No. ARB/06/1, Award, 7 December 2011, p. 117: „Since Article 1 of the First Additional Protocol of the European Convention creates far better treatment than Article 4 of the Treaty, Article 1 of the First Additional Protocol comes within the jurisdiction of the Tribunal."

53 Agreement between the government of Romania and the government of the Hellenic republic on the promotion and reciprocal protection of investments, ze dne 16. záři 1993, čl. 10: „Application of other Rules - If the provisions of law of either Contracting Party or obligations under international law existing at present or established hereafter between the Contracting Parties in addition to this Agreement, contain a regulation, whether general or specific, entitling investments by investors of the other Contracting Party to a treatment more favourable than is provided for by this Agreement, such regulation shall, to the extent that is more favourable, prevail over this Agreement."Je zajímavé, že v literatuře je bez dalšího uvedeno, že toto ustanovení je doložka nejvyšších výhod. Viz GHOURI, Ahmad Ali. Interaction and conflict of treaties in investment arbitration. Alphen aan den Rijn, The Netherlands: Kluwer Law International, 2015, xvii, 192 pages. ISBN 9041154175, s. 118-119.

54 Spyridon Roussalis, cit. supra n. 52, p. 312.

55 Mr. Franck. Charles Arif v. Republic of Moldova, ICSID Case No. ARB/11/23, Award, 8 April 2013, p. 389. 
sů dovolával za účelem inkorporace dalších hmotněprávních standardů, které základní dvoustranná dohoda neobsahovala. Dle investora toto ustanovení funguje jako doložka nejvyšších výhod. I v tomto případě tribunál odmítl akceptovat investorův přístup. $\mathrm{V}$ tomto př́padě bylo ustanovení formulováno negativně - dvoustranná dohoda neznamená, že se investor nemůže dovolávat výhodnějšího zacházení z jiného dokumentu. Neznamená to však, že se investor může domáhat aplikace tohoto výhodnějšího zacházení v mezinárodní investiční arbitráži. ${ }^{56}$

Přehled judikatury, kdy došlo k argumentaci ustanovením o použití jiných předpisů, ukazuje, že strany se snažily využít toto ustanovení různě. Snažily se tak překonat individuální problémy jejich nároků. Ustanovením bylo argumentováno za účelem dosažení efektu doložky nejvyšších výhod k rozšíření pravomoci rozhodčího tribunálu (Accession Mezzanine, Yang Chi Oo Trading, TSA Spectrum, Spyridon Rousalis v. Rumunsko nebo Íckale Inşaat v. Turkmenistán), za účelem rozšírení pravomoci tribunálu na nároky vzniklé ze smluvního závazku (Salini v Jordánsko nebo Arif v. Moldávie), ale i za účelem vyloučení použitelnosti národního práva na otázky, které jinak nejsou upraveny v úmluvě a rozšírení mezinárodního práva na tyto otázky (William Nagel v. Česká republika), ale taktéž za účelem rozšíření aplikovatelnosti dvoustranné úmluvy z hlediska časového (M.C.I. Power v. Ekvádor a Nordzucker v. Polsko). Nejčastěji se snažili investoři rozšíŕit spektrum otázek, které mohli předložit rozhodčímu tribunálu, a tím si rozšířit mezinárodní odpovědnost států vůči nim.

\section{Pohled odborné literatury na ustanovení o použití dalších ustanovení}

Roztřrištěná interpretace ohledně předmětného ustanovení se vyskytuje i v odborné literatuře. Jak uvádí Newcombe a Paradelle, text ustanovení odkazující na nejvýhodnější zacházení indikuje, že by mohlo jít o doložku nejvyšších výhod. ${ }^{57}$ Podstatným rozdílem je však rozsah pramenů, z nichž je možné čerpat toto výhodnější zacházení. Zatímco doložka nejvyšších výhod odkazuje na výhody poskytnuté hostitelským státem investorům z jiných států (tj. jejím základem je zásadně mezinárodní právo - úmluvy uzavřené mezi hostitelským státem a třetími státy), ustanovení o použitelnosti jiných předpisů odkazuje na mezinárodní právo aplikovatelné mezi smluvními stranami dohody, případně na vnitrostátní právní úpravu. ${ }^{58}$

V literatuře se taktéž objevuje i názor, že jde o ustanovení s obdobným účinkem, jako má zastřešující klauzule. Tento názor se odvijí od toho, že předmětné ustanovení umožňuje odkazy na zvláštní smlouvy, na základě kterých došlo k uskutečnění investice. V pří-

56 İckale Inşaat Limited Şirketi v. Turkmenistan, ICSID Case No. ARB/10/24, Award, 8 March 2016, p. 331.

57 NEWCOMBE, Andrew Paul a Lluís PARADELL. Law and practice of investment treaties: standards of treatment. Austin: Wolters Kluwer, 2009, xxx, 614 s. ISBN 978-90-411-2351-0, s. 317.

58 Ibid, s. 317. 
padě, že tato zvláštní smlouva obsahuje ustanovení výhodnější (ustanovení, dle kterého je investorovi poskytováno výhodnější zacházenî), má takováto zvláštní smlouva přednost. Dle prezentovaného názoru je efekt ustanovení o použití jiných předpisů zrcadlovým k zastřešující klauzuli - zatímco zastřešující klauzule působí z pohledu hostitelského státu, který zavazuje („,nutí‘) k dodržení závazků, které na sebe převzal, ustanovení o použití jiných předpisů má působit z pohledu investorů, když jim zajišt'uje použití výhodnějšího zacházení, které je upraveno ve zvláštní smlouvě uzavřené s investorem. ${ }^{59}$

$\mathrm{V}$ komentářích zaměřených na texty konkrétních dvoustranných dohod o podpoře a ochraně investic je toto ustanovení specificky uváděno jenom zřídka. Dle komentáre k řeckým dvoustranným smlouvám autor uvádí, že toto ustanovení neumožňuje asimilovat (dosáhnout) mezinárodního statusu pro smluvní závazky hostitelského státu. Taktéž toto ustanovení neukládá hostitelskému státu další dodatečné povinnosti v rámci rozsahu dvoustranných dohod. ${ }^{60}$

Stejný názor je prezentován i v komentári k britským smlouvám. Podle prezentovaného názoru toto ustanovení nepřidává žádný další standard ochrany, který by byl předmětem pravomoci rozhodčího tribunálu, rozhodujícího spory mezi investorem a hostitelským státem. Tento komentář výslovně vylučuje, že by mohlo jít o zastřešující klauzuli. ${ }^{61}$

V kontextu německých dvoustranných dohod je ustanovení o jiných předpisech taktéž odlišeno od zastřešující klauzule. Dle komentáře mají tato ustanovení systematicky odlišné účinky. Ustanovení o jiných předpisech jednoduše ponechává uplatnitelnou národní právní úpravu nebo mezinárodněprávní závazky netknuté předmětnou dohodou o ochraně investic. To znamená, že výhodnější zacházení poskytované národním právem nebo mezinárodním právem není nahrazeno úpravou v dohodě o ochraně investic. $\mathrm{Na}$ rozdíl od tohoto účinku, zastřešující klauzule vytváří povinnost/závazek podle dohod o ochraně investic. ${ }^{62}$

Obdobně je účinek ustanovení o použití jiných předpisů popisován v komentáři k rakouským dvoustranným dohodám o ochraně investic. Dle komentáře jde o ustanovení zabezpečující, aby ustanovení dvoustranné dohody nenahradilo národní právní úpravu nebo mezinárodní závazky z titulu speciální právní úpravy (lex specialis) nebo novější právní úpravy (lex posterior). ${ }^{63}$

59 GALLAGHER, Norah a Wenhua SHAN. Chinese investment treaties: policies and practice. New York: Oxford University Press, 2009, lix, 592 p. ISBN 0199230250, s. 230-231.

60 PAPAEFSTRATIOU FOUCHARD, Athina. Bilateral Investment Treaty Overview - Greece.: IC-OV 021 GR(2010) [online]. [cit. 2015-10-18]. Dostupné z: http://oxia.ouplaw.com/view/10.1093/law:iic/ ov-gr.document.1/law-iic-ov-gr?rskey=5s6GFx, p. D41.

61 BROWN, Chester. Commentaries on selected model investment treaties. First edition. Oxford, United Kingdom: Oxford University Press, 2013, cxxi, 895 pages. Oxford commentaries on international law. ISBN 0199645191, s. 749-750.

62 Ibid, s. 313-314.

63 Ibid, s. 36. 
Komentář k modelové dohodě Spojených států amerických jenom lakonicky opakuje, že předmětné ustanovení má za účel zabránit, aby dvoustranná dohoda odňala investorovi nebo jeho investici výhodnější zacházení, které je poskytováno na základě národního právního řádu hostitelského státu, mezinárodních závazků hostitelského státu a závazků, které hostitelský stát převzal povolením investice nebo v dohodě o investici. ${ }^{64}$

\section{Obsah ustanovení o použití jiných předpisů}

Samotný text ustanovení o použití jiných předpisů se v českých dvoustranných dohodách o podpoře a ochraně investic vyskytuje v podobném, avšak nikoli identickém znění. Vủbec první dvoustranná dohoda, která byla Československem uzavřena, Dohoda mezi Československou socialistickou republikou a Hospodářskou unií belgicko-lucemburskou o vzájemné podpoře a ochraně investic, ${ }^{65}$ má toto ustanovení formulováno následně:

„1. Tato Dohoda nemůže bránit investorum využivat výhodnějši ustanoveni právního rádu, platného na územi smluvni strany, kede jsou investice umistèny, nebo mezinárodnich smluv, jimiž jsou obè smluvní strany vázány.

2. Investori jedné smluvni strany mohou uzavrìt s drubou smluvni stranou zulástni smlouvy, jejichž ustanoveni však nemohou být v rozporu s touto Dohodou. Investice uskutečnèné podle těch to zuláštnich smluv se budou rídit jejich ustanovenimi, jakož i ustanovenimi této Dohody. "66

Pro srovnání uved’me, jak je formulováno obdobné ustanovení v dohodě, která byla Českou republikou sjednána zatím jako poslední. Je jí Dohoda mezi Českou republikou a Ázerbájdžánskou republikou o podpoře a vzájemné ochraně investic, ${ }^{67}$ která předmětné ustanovení formuluje následovně:

„1. V prǐpadě, že je některá otázka rèsena současnè touto dohodou a jinou mezinárodni dohodou, jejímiž stranami jsou obè smluvni strany, nic v této dohodè nebrání, aby jakákoli smluvni strana nebo jakýkoli jeji investor, který vlastni investice na územi drubé smluvni strany, vyuřil jakýchkoli pravidel, k.terá jsou pro něbo prìznivějš̀t.

2. Jestliže zacházeni poskytnuté jednou smluvni stranou investorim drubé smluvni strany v souladu s jejími unitrostátními právními predpisy nebo jinými zulástními smluvními ustanoveními je př̃̃nivèjsí, než keteré je poskytováno touto dohodou, bude poskytnuto toto prǐznivèjsí zacházeni. "“68

\footnotetext{
64 Ibid, s. 811.

65 Publikována pod č. 574/1992 Sb.

66 Čl. 6.

67 Publikována jako č. 14/2012 Sb.m.s.

68 Čl. 12.
} 
Jako formulačně výrazně odlišné je vhodné ještě uvést formulace v dohodách uzavřených se Spojenými státy americkými a Finskem:

„Tato Dohoda nesníži úcinnost

a) zákonu a predpisü, administrativnípraxe nebo postupio administrativnich či soudnich rozhodnutí obou smluvnich stran;

b) mezinárodnich práunich závazkị; nebo



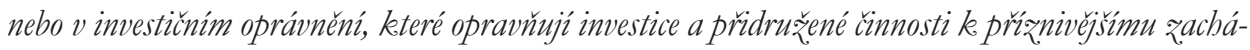
zeni než v podobných situacich priznnává tato Dohoda. “69

„Obsabuji-li právni predpisy jedné smluvni strany, nebo mezinárodnèprávni závazky, keteré plati vedle této Dohody mezi smluvnimi stranami nebo budou platit v budoucnu, obecnou nebo zvláštni úpravu, která poskytuje investicím investori drubé smluvni strany př̌nnivèjsí zacházeni než tato, má taková

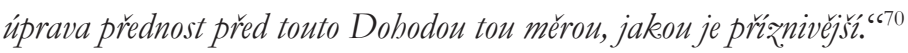

Všechna výše prezentovaná ustanovení obsahují pravidlo pro řešení prrípadného konfliktu s třemi prameny práva:

- smlouva uzavřená mezi investorem a hostitelským státem;

- národní právní úprava hostitelského státu a

- mezinárodní právní závazky, které mohou být zúženy na mezinárodní smlouvy, které zavazují smluvní strany předmětné dohody o podpoře a ochraně investic. ${ }^{71}$

V kontextu českých dohod o ochraně investic můžeme dle rozsahu ustanovení o použití jiných předpisů rozlišit několik skupin dvoustranných dohod. Nejpočetnější skupi-

69 Čl. IX Dohody mezi Českou a Slovenskou Federativní Republikou a Spojenými státy americkými o vzájemné podpoře a ochraně investic, publikována pod č. 187/1993 Sb.

70 Čl. 7 Dohody mezi Českou republikou a Finskou republikou o podpoře a ochraně investic, publikována pod č. 478/1991 Sb.

$71 \mathrm{~V}$ př́padě dohod uzavíraných Českou republikou je rozsah omezen na mezinárodní dohody v př́padech dohod uzavřených s Albánií, Argentinou, Ázerbájdžánem, Bahrajnem, Hospodářskou unií belgicko-lucemburskou, Běloruskem, Bosnou a Hercegovinou, Bulharskem, Černou Horou, Čínou, Egyptem, Filipínami, Gruzií, Guatemalou, Chile, Jemenem, Jihoafrickou republikou, Jordánskem, Kambodži, Kanadou, Kazachstánem, Korejskou republikou, KLDR, Kosovem, Kostarikou, Kyprem, Litvou, Lotyšskem, Mad'arskem, Makedonií, Malajsií, Marokem, Mauriciem, Mexikem, Moldavskem, Mongolskem, Nikaraguou, Panamou, Paraguayím, Peru, Polskem, Rumunskem, Ruskem, Salvadorem, Spojenými arabskými emiráty, Srbskem, Sýrií, Tádžikistánem, Tuniskem, Ukrajinou, Uruguayem, Uzbekistánem a Vietnamem). Odkaz na obecné mezinárodní závazky obsahují dohody uzavřené s Finskem, Chorvatskem, Indií, Indonésií, Izraelem, Kuvajtem, Libanonem, Německem, Portugalskem, Rakouskem, Řeckem, Saúdskou Arábií, Singapurem, Spojenými státy americkými, Švédskem, Spojeným královstvím a Venezuelou. 
na 45 dohod $^{72}$ obsahuje všechna tři ustanovení, tj. ustanovení odkazuje na výhodnější uplatnění vnitrostátního zákona, zvláštní smlouvy uzavřené s investorem i výhodnější uplatnění mezinárodního práva závazného mezi smluvními stranami dvoustranné dohody o ochraně investic. Další velká skupina 23 dvoustranných dohod ${ }^{73}$ uplatnění tohoto ustanovení omezuje jenom na vnitrostátní zákon a mezinárodní právo účinné mezi smluvními stranami dohody o ochraně investic. Dvě dvoustranné dohody o ochraně investic upravují jenom výhodnější uplatnění bud' vnitrostátního práva, ${ }^{74}$ zvláštní smlouvy uzavřené s investorem, ${ }^{75}$ nebo mezinárodního práva účinného mezi smluvními stranami dohody o ochraně investic (mezinárodní smlouvy účinné mezi nimi). ${ }^{76}$ Ve čtyřech př́padech žádné takovéto ustanovení dohoda o ochraně investic neobsahuje. ${ }^{77}$

\section{1 ̌ešení konfliktu dvoustranné dohody se zvláštní smlouvou mezi investorem a hostitelským státem}

Tato část ustanovení směřuje k podtrhnutí přednosti dohody stran. Z povahy věci nemůže být mezinárodní smlouva uzavřená mezi státy zásadně odsunuta smluvní úpravou, která má základ v národním právu (jiný právní základ zvláštní smlouva mezi investorem - fyzickou nebo právnickou osobou a hostitelským státem nemưže mít, i když to nemusí být vždy národní právo hostitelského státu, jelikož smluvní autonomie a možnost zvolit si právní řad dohodou stran se uplatní i v tomto př́ípadě ${ }^{78}$ ). Až takovéto ustanovení v mezinárodní smlouvě dovoluje dát přednost úpravě individuálně dohodnuté mezi investorem a hostitelským státem.

72 Jedná se o dohody s Albánií, Argentinou, Ázerbájdžánem, Bahrajnem, Hospodářskou unií belgicko-lucemburskou, Bosnou a Hercegovinou, Egyptem, Filipínami, Gruzií, Guatemalou, Chile, Jemenem, Jihoafrickou republikou, Jordánskem, Kambodžou, Kazachstánem, Korejskou republikou, KLDR, Kostarikou, Kyprem, Litvou, Lotyšskem, Mad’arskem, Makedonií, Malajsií, Mauriciem, Moldavskem, Mongolskem, Nikaraguou, Panamou, Paraguayem, Peru, Rumunskem, Salvadorem, Saúdskou Arábií, Spojenými arabskými emiráty, Spojenými státy americkými, Sýrií, Tádžikistánem, Tuniskem, Ukrajinou, Uruguayem a Uzbekistánem.

73 Jde o dohody s Běloruskem, Bulharskem, Černou Horou, Finskem, Chorvatskem, Indií, Indonésií, Izraelem, Kosovem, Kuvajtem, Libanonem, Marokem, Německem, Polskem, Portugalskem, Rakouskem, Ruskem, Řeckem, Singapurem, Srbskem (jde původně o dohodu uzavřenu se Svazovou republikou Jugoslávií, která se momentálně vztahuje i na Kosovo a Černou Horu), Švédskem, Spojeným královstvím a Venezuelou.

74 Jde o dohody uzavřené s Austrálií a Švýcarskem.

75 Jde o dohody uzavřené s Francií a Španělskem.

76 Jde o dohody uzavřené s Kanadou a Mexikem.

77 Jde o dohody uzavřené s Nizozemím, Norskem, Tureckem a Thajskem.

78 Case concerning the Payment of Various Serbian Loans Issued in France (France v. Serbia), PCIJ Rep. Series A No. 20, s. 41. Argumentace, dle které jsou takovéto smlouvy podřizeny ne právu hostitelského státu, ale nějaké formě nadnárodních nebo mezinárodních pravidel (internacionalizace) byla vznesena, avšak není obecně prijímana. Viz k tomu blíže VOSS, Jan Ole. The impact of investment treaties on contracts between host states and foreign investors. Boston: Martinus Nijhoff Publishers, 2011, xxxviii, 363 p. Studies on the law of treaties, v. 4. ISBN 9004192239, s. 25-50. 


\section{2 Řešení konfliktu dvoustranné dohody a národního práva hostitelského státu}

Z pohledu mezinárodního práva, a tedy i z pohledu dohody o podpoře a ochraně mezinárodních investic, je národní právo jenom faktickou skutečností, která se v tomto kontextu posuzuje zásadně jenom z pohledu, zda jeho realizací došlo k porušení standardů chráněných dohodou o podpoře a ochraně investic. Ustanovení o použití jiných předpisů se na tuto otázku dívá z jiného úhlu. Místo odkazu na přednost mezinárodního práva a jeho aplikace odkazuje na „primát“ práva národního, ale jenom ve specifickém rozsahu. Ustanovení zabezpečuje, že dohoda o ochraně investic neneguje uplatnitelnost národního práva, které má možnost uplatnit se $\mathrm{v}$ př́ípadech, kdy poskytuje výhodnější zacházení pro investora nebo jeho investici. ${ }^{79}$ Takováto interpretace byla předvídána i při sjednávaní dvoustranných dohod. ${ }^{80}$

\section{3 ̌̌ešení konfliktu dvoustranné dohody a mezinárodních závazků}

Je obecně známou skutečností, že mezinárodní právo neobsahuje přesnou hierarchii pramenů, která je typická pro národní právní rády, které jsou tvořeny ústředním zákonodárcem. ${ }^{81}$ Proto vztahy mezi prameny mezinárodního práva nejsou určitelné z povahy jejich právní síly. Dalším komplikujícím prvkem je možnost úpravy stejných nebo obdobných otázek $\mathrm{v}$ pramenech, které zavazují někdy jen jeden stát (jednostranné prohlášenî), někdy dva (dvoustranné úmluvy), někdy tři a více (více a mnohostranné úmluvy, obyčejové právo).

Konflikt smluvních pramenů je regulován obecně ve Vídeňské úmluvě o smluvním prá$\mathrm{vu}^{82} \mathrm{v}$ čl. 30. S odkazem na čl. 103 Charty Organizace Spojených národư ${ }^{83}$ je pamatováno na uplatnění hierarchie $\mathrm{v}$ mezinárodním právu ve prospěch přednosti závazků z Charty

79 Zahrnutí předmětného ustanovení do textu dohody působí proti jinak obecnému pravidlu, dle kterého $\mathrm{v}$ př́ípadě, že mezinárodní smlouva stanoví něco jiného než vnitrostátní právo, má přednost před vnitrostátní úpravou, jak je upraveno v čl. 1 Ústavy ČR.

80 Viz např. INFORMACE pro s. nám. Pavelku: „Britský návrh se v tomto př́padě zrèmé snaží zabezpečit pro své investory nejlepši možné zacházeni / v prípadě, že by napr̆. Zákon č. 173/1988 Sb., o podnicich se zabranični majetkovou účastí nebo jeho novela obsahovaly ustanoveni výhodnèjsí než to, keteré by bylo zakotveno ve smlouvěl."

81 Vienna convention on the law of treaties: a commentary. Berlin: Springer, 2012, liv, 1423 s. ISBN 9783642192906 , s. 506; MALENOVSKÝ, Jiří. Mezinárodní právo verejné: jeho obecná část a pomèr k jinyim právním systémuim, zuláště k právu čskému. 5., podstatně upr. a dopl. vyd. Brno: Masarykova univerzita, 2008, 551 s. ISBN 978-80210-4474-6, s. 23, 27, 176.

82 Publikována pod č. 15/1988 Sb.

83 „V prípadě rozporu mezi závazky členù Organizace podle této Charty a jejüch qúvazky podle kterékoli jiné mezinárodní dohody, maji prednost závazky podle této Charty." Charta OSN byla publikována pod č. 30/1947 Sb. 
OSN před odlišnými (protichůdnými) závazky z jiných úmluv. ${ }^{84}$ Takováto výslovná úprava však není dostupné v př́padě konfliktu s obyčejovým mezinárodním právem.

Nejjistějším způsobem předcházení případným konfliktům smluvní úpravy (ale i případného konfliktu s obyčejovým právem) a případně jejich co nejjednodušším a nejefektivnějším řešením je výslovná úprava. ${ }^{85}$ Článek 30 odst. 2 Vídeňské úmluvy o smluvním právu výslovně pamatuje na situaci, kdy smluvní strany upraví ve smlouvě, že předmětná smlouva nebrání aplikaci jiných úmluv. ${ }^{86} \mathrm{~V}$ případě, že úmluva neobsahuje ustanovení výslovně řešící konflikt s jinou úpravou, je nutné rozlišovat dvě situace. Zaprvé konflikt úprav se stejnými smluvními stranami, kdy se uplatní klasický princip lex posterior. Zadruhé prrípad, kdy rozsah smluvních stran již není úplně stejný, kdy je nutné strukturovat odpovídající pravidla podle toho, které závazky jsou platné mezi kterými smluvními stranami.

$\mathrm{V}$ př́padě dvoustranných smluv o podpoře a ochraně investic to znamená, že mezi smluvními stranami není možné bez dalšího uplatnit právní úpravu, která není závazná pro obě smluvní strany. ${ }^{87}$ Takovou výjimkou, kdy dochází k uplatnění právní úpravy ze smlouvy, která má s dvoustrannou smlouvou o podpoře a ochraně investic společnou jen jednu smluvní stranu, je aplikace doložky nejvyšších výhod.

Až ustanovení o použití jiných předpisů umožňuje specifickou aplikaci mezinárodní úpravy výhodnější pro investora i v prípadě, kdy nejde o ustanovení novější. Jde tedy o specifické řešení konfliktu mezinárodních závazků. Jde o řešení uplatnitelné jak na konflikt v smluvní úpravě, ale taktéž na konflikt s obyčejovým právem. ${ }^{8}$

\subsection{Zacházení}

Důležitou otázkou související s ustanovením o použitelnosti jiných předpisů je otázka, co všechno je možné považovat za „zacházení،, které má být výhodnější pro investora nebo jeho investici. V kontextu ustanovení o použití jiných předpisů není termín

84 Jak uvádí Čepelka, není to jen odkaz na smluvní úpravu, ale i době vzniku úpravy poplatné upozornění na existenci ius cogens, kterého součásti byly zahrnuty do Charty. ČEPELKA, Čestmír. Právo mezinárodnich smluv: Videñská úmluva o smluvním právu (1969) - s komentárem. 1. vyd. Praha: Karolinum, 1999, $202 \mathrm{~s}$. ISBN 80-7184-970-7, s. 50-51. Tato další hierarchická přednost kogentních pravidel je uvedena v čl. 53 VCLT.

85 Vienna convention, cit. supra n. 79, s. 513; ČEPELKA, cit. supra n. 82, s. 51, 53.

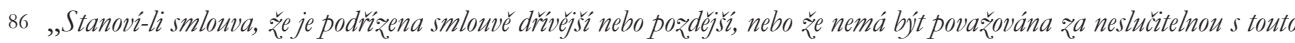
drubou smlowvou, maji ustanoveni této drubé smlowy prednost.“ Jde o tzv. „conflict clause, saving clause, compatibility clause“. Jak uvádí literatura, je ještě jeden možný způsob úpravy konfliktu mezi smluvní úpravou. A tím je prohlášení přednosti předmětné smlouvy před úpravou jinou. Nejrozšířenějším případem takovéto přednosti je čl. 103 Charty OSN. Viz Vienna convention, cit. supra n. 79, s. 512-513.

87 Vienna convention, cit. supra n. 79, s. 513-515.

88 V konkrétním prípadě bude rozsah záviset od formulace ustanovení o použíti jiných předpisů. Může jít o př́pady, kdy je výslovně uváděna jenom „mežinárodní dohoda“ nebo obecně mezinárodní závazky. Viz supra n. 69. 
„zacházeni'“ zvlášt’ řešen. 'Tento termín byl ale důležitou otázkou v kontextu doložky nejvyšších výhod.

Klíčovou otázkou je rozlišování, co všechno je možné považovat za zacházení - zda jenom uplatnění hmotněprávních standardů, nebo i uplatnění procesní ochrany, zejména možnosti dovolat se specifického řešení sporů. ${ }^{89}$

Specifické rozlišení zacházení s investorem nebo s investicí a možnost nahradit specificky dohodnutý způsob řešení sporů mezi hostitelským státem a investorem učinil např. tribunál ve věci Plama Consortium rozhodovaný na základě dvoustranné dohody mezi Bulharskem a Kyprem..$^{90}$ Zdůraznění, že ,zacházení “ se týká hmotněprávní úpravy ochrany investora je možné nalézt např. v rozhodnutí Wintershall. ${ }^{11}$

Podrobné rozlišení těchto dvou okruhů otázek poskytl tribunál ve věci $S T$ - $A D$ vedené německým investorem proti Bulharsku na základě dohody mezi Bulharskem a Německem. Jak uvádí tribunál ve svém rozhodnutí, před tím, než může být rozhodci v rozhodčím řízení poskytnuto výhodnější zacházení, musí existovat investor a investice ve smyslu dvoustranné dohody o ochraně investic. Za výhodnější zacházení v kontextu dvoustranné smlouvy není možné považovat širší okruh toho, co je považované za investici nebo investora. Dále musí být dvoustranná dohoda použitelná časově (ratione temporis), věcně (ratione materiae) a tribunál musí mít pravomoc předvídanou dohodou (má pravomoc ratione voluntatis). Žádný z těchto předpokladů není možné rozšírit nebo jinak upravit působením výhodnějšího zacházení v rámci jedné dohody o ochraně investic. ${ }^{92}$ Je vhodné uvést, že takovéto striktní rozlišování se nemusí týkat procesního zacházení dle národního práva, ${ }^{93}$ ale nemůže to znamenat rozšíření tohoto výhodnějšího procesního postupu umožněného národním právem do procesního postupu předvídaného dvoustrannou dohodou o ochraně investic. ${ }^{94}$

89 Viz např. European American Investment Bank AG (EURAM) v. Slovak Republic, UNCITRAL, Award on Jurisidiction, 22 October 2012, p. 451.

90 Plama Consortium Limited v. Republic of Bulgaria, ICSID Case No. ARB/03/24, Award, 27 August 2008, p. 209. Viz též Kilıç Inşaat Ithalat İhracat Sanayi ve Ticaret Anonim Şirketi v. Turkmenistan, ICSID Case No. ARB/10/1, Award, 2 July 2013, pp. 7.8.1 - 7.8.10. Méně kategorické stanovisko je možné nalézt např. v rozhodnutí Austrian Airlines v. The Slovak Republic, UNCITRAL, Final Award, 9 October 2009, p. 126.

91 Wintershall Aktiengesellschaft v. Argentine Republic, ICSID Case No. ARB/04/14, Award, 8 December 2008, p. 168.

92 ST-AD GmbH v. Republic of Bulgaria, UNCITRAL, PCA Case No. 2011-06, Award on Jurisdiction, 18 July 2013, p. 397. Obdobně v kontextu věcného rozsahu rozhodl i tribunál ve věci Metal-Tech Ltd. v. Republic of Uzbekistan, ICSID Case No. ARB/10/3, Award, 4 October 2003, p. 145.

93 Daimler Financial Services AG v. Argentine Republic, ICSID Case No. ARB/05/1, Award, 22 August 2012, p. 227.

94 Les Laboratoires Servier, S.A.A., Biofarma, S.A.S., Arts et Techniques du Progres S.A.S. v. Republic of Poland, UNCITRAL, Award, 14 February 2012, p. 519. 
Naopak jiné rozhodnutí nepovažovala toto rozlišení za podstatné. Rozhodnutí odvíjející se od případu Maffez̨ini ${ }^{95}$ v rámci výhodnějšího zacházení v kontextu doložky nejvyšších výhod akceptovala i upravení doložky o řešení sporů ve prospěch žalujícího investora, kdy místo původní tzv. cooling-off period, bylo akceptováno splnění kratší lhưty, kterou poskytovaly jiné dvoustranné dohody než dohoda, na základě které měla být vedena arbitráž. Avšak ani tato rozhodnutí neopravňují investora domáhat se dalšího nového oprávnění a nevytvářejí ani novou povinnost pro hostitelský stát.

I další investiční judikatura potvrzuje, že to, že někde může existovat výhodnější úprava pro investora, neznamená, že investor může takovouto úpravu vznést v arbitráži, když tato úprava, neboli „zacházení, je totiž vyloučena z rozsahu pravomoci rozhodčího tribunálu at' již z důvodu zúžené doložky o řešení sporů mezi hostitelským státem a investorem, nebo proto, že nejde o záležitost spadající pod materiální rozsah úpravy dohody (vymezení investora a investice, taktéž vymezení standardů ochrany poskytovaných dohodou). Jak potvrzuje rozhodovací praxe, ustanovení o použití jiných předpisů nemůže být použito k vytváření nových povinností hostitelského státu, resp. nových oprávnění a nároků, kterých se může investor domáhat. ${ }^{96}$

V př́padě, že předmětné výhodnější „zacházení“ skutečně obsahuje individuální nároky, tyto mají být uplatněny způsobem, který je pro ně předvídán v tomto právním předpisu, který toto výhodnější ,zacházeni““ reguluje. Mưže jít o volbu soudu ve smlouvě mezi investorem a hostitelským státem nebo o úpravu řešení sporů v národním právu. V poslední instanci se může investor obrátit na svůj domovský stát a požádat o uplatnění diplomatické ochrany. ${ }^{97}$

\section{Závěr}

Ustanovení o použití jiných předpisů jsou vkládána do dvoustranných smluv o ochraně a podpoře investic vcelku pravidelně. Obecně obsahují úpravu, která se investorovi umožňuje domáhat se použití výhodnější úpravy, která může být obsažena jednak ve vnitrostátním právu hostitelského státu, jednak ve smlouvě uzavřené mezi investorem a hostitelským státem, případně i v mezinárodním právu, které zavazuje obě smluvní strany dohody o ochraně investic.

95 Emilio Agustin Maffezini v. The Kingdom of Spain, ICSID Case No. ARB/97/7, Decision of the Tribunal on Objections to Jurisdiction, 25 January 2000, p. 54.

96 Accession Mezzanine, cit. supra n. 18, p. 73.

97 Telenor Mobile Communications A.S. v. The Republic of Hungary, ICSID Case No. ARB/04/15, Award, 13 September 2006, p. 81. Viz též CMS Gas Transmission Company v. Republic of Argentina, ICSID Case No. ARB/01/8, Award on Jurisdiction, 17 July 2003, p. 45. K uplatnění diplomatické ochrany a vyvolání mezistátní arbitráže došlo v př́padě Italian Republic v. Republic of Cuba, ad hoc state-state arbitration, na http://italaw.com/cases/580 [cit 11. 10. 2015]. 
Rozhodnutí vztahující se k tomuto ustanovení potvrzují, že jde o ustanovení, které má řešit př́ípadné konflikty mezi těmito zdroji právní úpravy zahraničních investic. I když se to neprojevilo $v$ jednotlivých prrípadech, kdy bylo přímo argumentováno těmito ustanoveními, tato rozhodnutí potvrzují, že není vyloučeno, aby se investor domáhal výhodnější úpravy. To však neznamená, že se této hypotetické výhodnější úpravy může investor domáhat pred mezinárodním rozhodčím tribunálem, tj. pro investora zatím nejvýhodnějším sudištěm. 